\title{
As (Im)Possibilidades de Sustentabilidade do Modo de Vida Ribeirinho: Estudo sobre um Grupo Social na Área Insular do Município de Belém-Pa
}

\author{
João Luiz da Silva Lopes*
}

\begin{abstract}
Resumo:
O estudo propõe-se a compreender e explicitar o modo de vida ribeirinho, referentes a sua produção social (material e simbólica) relacionada ao tempo ecológico e sua interação com outras lógicas temporais e econômicas. $\mathrm{Na}$ intenção de poder contribuir com a desconstrução e superação da idéia que concebe este segmento como população preguiçosa, isolada e em atraso espacial e temporal. A perspectiva da complexidade orientou a percepção sobre a realidade investigada, a partir de pesquisa qualitativa. Os resultados da pesquisa mostram que os valores culturais, as simbologias, as condições naturais que variam de acordo com os ritmos ecológicos, os equipamentos técnicos, influenciam na organização socioambiental, orientam a realização das práticas produtivas e garantem a reprodução dos ribeirinhos nas franjas dos processos econômicos dominantes, a partir de estratégia que combina a vivência no cruzamento dos tempos ecológico e mecânico. Menciona-se a necessidade da construção de uma abordagem complexa que permita a percepção da co-existência, da tensão, do antagonismo, do conflito e da complementaridade, entre os vários tempos e lógicas econômicas. Assim como a compreensão da correlação de forças, na forma de conceber o ambiente, em escala local, regional, nacional e global.
\end{abstract}

Palavras-chave: Ribeirinho, tempos, práticas econômicas, ambiente, complexidade.

\begin{abstract}
:
This study aims to comprehend and make explicit the specific matters about the river people, referring to their social production (material and symbolical) related to the ecological time and their interaction with other economic and time logics. The intention is to encourage the overcoming of the idea that this part of the population is lazy, geographically isolated, and spatially and temporally retrograde. The perspective of the complexity guided the perception about the analyzed reality, in a qualitative research. The research's results show that the cultural values, the symbology, the natural conditions that vary according to the ecological rhythms,
\end{abstract}

\footnotetext{
* Bacharel e licenciado pleno em Ciências Sociais pela Universidade Federal do Pará (1997), Especialista em Produção Familiar Rural e Ciências Sociais pela Universidade Federal do Pará e mestre em Sociologia pela Universidade Federal do Pará (2006). Atualmente é professor da Prefeitura Municipal de Belém.
}

Latitude, vol. 5, n², pp.75-109, 2011

DOI: https://doi.org/10.28998/2179-5428.20110205 


\section{As (Im)Possibilidades de Sustentabilidade do Modo de Vida Ribeirinho: Estudo sobre um Grupo Social na Área Insular do Município de Belém-Pa}

and the technical equipments have influence on the social and environmental organization. They guide the performance of the productive practice and guarantee the propagation of the river people on the edge of the dominating economic process, by using a strategy that combines both ecological and mechanical time. It is mentioned the necessity of a complex approach that makes it possible to notice the coexistence, the tension, the antagonism, the conflict and the complementarity between the various economic times and logics. As much as the comprehension of the correlation between forces concerning the environment in a local, regional, national and global scale.

Key-words : River people, times, economic practices, environment, complexity.

\section{Introdução}

As reflexões contidas neste trabalho, de acordo com a perspectiva que sigo, considera as relações dinâmicas e, portanto, não redutíveis às estruturas formais de explicação, procuram contribuir com o debate sobre o futuro do modo de vida ribeirinho, a partir de uma experiência concreta e recorrente que tem possibilitado a interação da bio-socio-diversidade nos contextos temporais e espaciais amazônicos. Procurando, também, avançar na superação das dicotomias entre cultura $\mathrm{x}$ natureza; atrasado $\mathrm{x}$ avançado; tradicional $\mathrm{x}$ moderno; tempo ecológico $\mathrm{x}$ tempo do relógio; produção para o mercado x produção para subsistência, etc.

Desse modo, o estudo enfatiza a questão temporal relacionada às práticas econômicas. Entendendo-se que a análise sobre o tempo traz as marcas da história, das tensões, das incompatibilidades, das contradições e dos conflitos inerentes a todo grupo social. Assim, a categoria tempo analisada na perspectiva das ciências sociais possibilita a apreensão das complexidades da realidade sociocultural jamaciense.

A perspectiva da complexidade, para a qual o conhecimento é concebido como um processo multidimensional, marcado pela multiplicidade, pela diversidade e pela complementaridade, orienta a nossa percepção sobre a realidade investigada.

É, então, nessa perspectiva que tratarei de um estilo de vida ribeirinho, a partir de uma experiência sócio-ambiental complexa. Numa situação em que as relações sociais encontram-se imbricadas com os ritmos ecológicos, devido à intensa relação cotidiana com o meio ambiente físico, a que chamarei de tempo ecológico. A influência do tempo ecológico imprime certa especificidade na lógica temporal desse segmento social, em relação à lógica econômica capitalista, que é baseada no tempo do relógio e não considera os limites dos recursos naturais nem as conseqüências ecológicas. 
É neste sentido que se problematiza a possibilidade de essa categoria tempo ecológico contribuir para a constituição de um saber ambiental, proporcionando a regulação da produção e orientando um comportamento tecnológico compatível com a sustentabilidade. Porém, é preciso deixar claro que não se pode conceber a relação entre a lógica temporal "moderna" da economia capitalista e a lógica temporal "tradicional" da pequena produção ribeirinha, apenas como excludente e sim numa perspectiva complexa, que permita a explicitação das relações socioambientais entre os jamacienses, entre eles e o meio ecológico e entre eles e a sociedade regional, numa visão de processo, considerando as relações históricas de conflitos. A fusão dessas duas lógicas vividas pelos jamacienses, numa relação de tensão, conflito e complementaridade, sugere a postulação de uma nova racionalidade ambiental e social.

A partir de observações diretas e através de estudos sobre as populações ribeirinhas como CASTRO (1999); CONCEIÇÃO (2001); HIRAOKA (1993); LEITÃO (1997); MAYBURY-LEWIS (1997); MOREIRA (2002) e SIMONIAN (2004) dirigi a atenção à lógica de organização social dessas populações relacionada ao tempo ecológico/natural, a qual apresenta especificidades em relação à lógica econômica capitalista baseada no tempo mecânico/cronometrado, visando à produtividade, ao lucro e à acumulação.

Um elemento que justifica a escolha do local é que o município de Belém é formado por $69,42 \%$ de área insular, constituída de 42 ilhas. Desse conjunto, a Ilha de Paquetá é a sétima maior com 715,83 hectares (PREFEITURA MUNICIPAL DE BELÉM, 1999).

A escolha da comunidade do Jamaci na ilha de Paquetá, localizada no município de Belém, ocorreu por razões consideradas relevantes do ponto de vista teórico e prático. A abordagem da pesquisa privilegia a experiência socioambiental concreta desse pequeno agrupamento social de setenta e cinco moradores formada por um grupo de dezessete unidades domésticas ${ }^{1}$, distribuídas ao longo das margens do igarapé Jamaci - a partir de um trabalho de campo de natureza qualitativa.

\section{Aspectos teóricos}

Num sentido mais geral, pode-se dizer que os atuais moradores do Jamaci fazem parte ou são resultantes de um processo de miscigenação que teve início

\footnotetext{
${ }^{1}$ Por unidade doméstica consideram-se as pessoas que vivem numa determinada residência, tomando por base as trocas matrimoniais entre os cinco grupos familiares e outros que vão se ramificando dos mesmos. A não utilização da noção "grupo doméstico", se justifica pelo fato de que na situação analisada, boa parte destas, não se constitui em unidades de produção e consumo.
}

Latitude, vol. 5, n², pp.75-109, 2011. 


\section{As (Im)Possibilidades de Sustentabilidade do Modo de Vida Ribeirinho: Estudo sobre um Grupo Social na Área Insular do Município de Belém-Pa}

com a chegada dos europeus e, posteriormente, de escravos negros africanos, que dão início à gestação de uma população não indígena, a mistura dessas três etnias (índio, negro e branco), comumente denominada de cabocla. Mas este termo, segundo LIMA (1999), deve ser entendido como uma categoria social empregada com base no reconhecimento de que a população rural amazônica compartilha um conjunto de atributos comuns, mas não é uma categoria homogênea e, sim, uma abstração.

Numa perspectiva histórica, MOREIRA NETO (1988), relata que os tapuios ${ }^{2}$ procuravam manter mecanismos de rejeição e de oposição à sociedade regional, preferindo sua vida primitiva, selvagem e independente em relação às vantagens do contato civilizador. Há considerações de que os tapuios procuraram defender sua identidade, como grupo social, construindo uma vida autônoma à margem da sociedade colonial.

Essa população também vem sendo identificada pelo termo ribeirinho, por habitarem as margens dos rios, neste caso ilha e igarapé, desenvolvendo atividades aquáticas, florestais e em alguns casos agrícolas (HIRAOKA, 1993). Essa é a definição que melhor expressa a situação jamaciense. Portanto, ribeirinho, neste trabalho, caracteriza um segmento social que interage com as águas e seus recursos cotidianamente, de forma combinada com os recursos da floresta (várzea), dispondo de conhecimentos e representações específicos relacionados ao ambiente em que vivem. Ou seja, não é apenas o fato de morar na beira do rio que caracteriza essas pessoas enquanto ribeirinho. É também um jeito de pensar e agir.

CASTRO (1999), ao analisar os processos de trabalho na Amazônia, menciona que os ribeirinhos:

[...] apóiam-se nos saberes sobre o tempo, as marés, os estoques e cardumes, as fases da lua e a ação das chuvas, para explicar seus processos de trabalho, a lógica de suas técnicas de captura e a invenção de sua vida social. $\mathrm{O}$ rio e o ciclo de águas são incorporados como dimensão fundamental da vida entre os povos das águas da Amazônia (CASTRO, 1999, p. 36).

É a partir desta perspectiva que consideramos uma cultura baseada numa racionalidade específica, que tem sobrevivido nos espaços e nos tempos amazônicos, contrariando certas teorias que prevêem seu desaparecimento.

A situação ribeirinha demonstra a necessidade de superação de análises simplistas que consideram essas realidades algo absolutamente regido pelas leis do

2 Moreira Neto (1988) chama de tapuio índios marcados pelo desenraizamento e pela aculturação intertribal e interétnica. $O$ tapuio é uma categoria intermediária entre o índio tribal e o caboclo, que procura se conservar à margem da sociedade dominante. 
capital, predestinadas a um futuro comum, e desafia a construção de um referencial alternativo que possibilite apreender e explicitar as peculiaridades sociais e culturais desse segmento social, abordando-o numa perspectiva complexa em que se possam pensar as várias possibilidades, no sentido de incorporação, de modificação, de destruição, de reinvenção e outras.

Outras vezes, essa realidade é interpretada como atrasada a partir de uma visão etnocêntrica e dicotômica, em relação a uma realidade moderna. Mas, vale ressaltar que a idéia aqui não é apresentar o ribeirinho, de modo geral, e o jamaciense, em particular, como um ser idílico e exótico, numa perspectiva romântica, como geralmente são concebidos pelo senso comum e pelas políticas de cunho desenvolvimentista, as quais tentam transformá-los em produtores inseridos num modelo empresarial baseado na racionalidade econômica da lógica capitalista.

A importância da desconstrução do modelo de análise simplista está referida em DURHAM (1982), quando reflete acerca dos problemas de método e interpretação:

Entretanto, o marxismo, voltado para uma visão macroestrutural centrada nas relações de produção e no desenvolvimento das forças produtivas, tendeu a reduzir a dimensão simbólica a reflexos supra-estruturais que não são em si explicativos dos conflitos e contradições que movem a sociedade. Mais ainda, tem-se revelado inadequado para analisar mesmo situações conjunturais, quanto mais peculiaridades sociais e culturais de segmentos específicos da população que constituem o grande campo de investigação dos antropólogos. Nessa tentativa de utilizar o marxismo, a Antropologia tem se revelado não apenas retardatária, mas inábil, contentando-se, muitas vezes, com uma projeção direta das grandes proposições relativas à luta de classes, à dominação ideológica, à exploração capitalista sobre os movimentos ou situações concretas de estudo: nessa projeção, as grandes explicações teóricas não são capazes de recuperar todas as ambigüidades, contradições e nuances reveladas pelo trabalho de campo. A teoria marxista é incapaz de explicar a complexidade, a ambigüidade e a riqueza dos fenômenos simbólicos que a análise antropológica revela. Além do mais, tendo em vista a generalidade e o simplismo da versão da teoria marxista com a qual os antropólogos em geral operam, a

Latitude, vol. 5, n², pp.75-109, 2011. 


\title{
As (Im)Possibilidades de Sustentabilidade do Modo de Vida Ribeirinho: Estudo sobre um Grupo Social na Área Insular do Município de Belém-Pa
}

\begin{abstract}
particularidade da análise empírica que realizam é irrelevante para as questões teóricas que colocaram de início. Desse modo, os trabalhos freqüentemente se movem em planos paralelos em que análise empírica e postulados teóricos jamais se confrontam. Por outro lado, a crítica da validade desses postulados gerais como elemento de integração da diversidade dos fenômenos estudados não tem produzido alternativas a não ser a fragmentação e dispersão das pesquisas na particularidade irredutível de cada caso (DURHAM, 1982, p. 166)
\end{abstract}

Ao invés de uma análise macroestrutural, baseada numa leitura evolucionista da penetração e expansão do capitalismo no meio rural-ribeirinho, que preconiza o desaparecimento desses modos de vida, optei por estudos empíricos sobre essas realidades concretas, as quais recolocam ou reavivam questões aparentemente superadas.

A problemática da ilha de Paquetá relacionada à permanência de uma lógica organizacional distinta da lógica capitalista supera, em termos teóricos, uma realidade puramente local, inserindo-se num debate teórico-político mais amplo, que nos remete ao futuro das comunidades camponesas/ribeirinhas ou Populações Tradicionais e da pequena produção mercantil associada à questão ambiental.

BAREL (1974) lembra que a pequena produção mercantil apresenta uma história muito mais longa que a capitalista e, embora sem nunca ter sido independente, sempre existiu, articulando-se a outras formas dominantes como a escravocrata, a feudal e a vigente. Um exemplo no Brasil é a situação analisada por FRANCO (1983) em Homens Livres na Ordem Escravocrata, que mostra nas franjas da ordem escravocrata a organização de uma população livre que garantia a produção e comercialização de alguns bens/gêneros que a monocultura não atendia.

A noção de mercado neste trabalho é baseada na concepção de ZELIZER (1992), a qual procura desconstruir a idéia de mercado ilimitado, questionando a autonomização e a diabolização do mercado. Além disso, sugere o modelo dos "mercados múltiplos", que procura superar a dicotomia entre processos econômicos, relações sociais e valores, ou seja, que há uma relação complexa, onde são criados, de forma dinâmica, novos modos de troca e repartição.

Neste trabalho, a noção de tempo ecológico, natural ou cíclico está relacionada à interpretação de EVANS-PRITCHARD (1978), segundo o qual essa noção é derivada das relações com o meio ambiente. Isto é, trata-se da influência e não de determinação do meio natural sobre os ribeirinhos. Segundo CUNHA (2000), que estudou a relação entre tempo natural e tempo mercantil na pesca artesanal, este 
tempo (ecológico ou natural) se expressa na relação estabelecida com a natureza. Ou seja, no modo como a natureza se impõe e concomitantemente é apropriada pelo pescador/ribeirinho, munido de tecnologia artesanal e conhecimento sobre o ambiente. Portanto, a aceitação de categorias como tempo ecológico/natural não significa, de forma alguma, a naturalização dos aspectos sociais e culturais. E sim a possibilidade de se pensar outras formas de relacionamento com o ambiente físico.

Diferentemente da noção de tempo mecânico ou tempo do relógio que, segundo THOMPSOM (1984), refere-se a uma consciência temporal que não utiliza como referência os fenômenos ecológicos ou naturais para a realização de atividades, está mais diretamente relacionada às dinâmicas industriais.

Num sentido mais amplo, o tempo é uma construção social com significado variado nas diversas sociedades e no seio de cada uma delas, de acordo com os diferentes grupos e contextos. Como sugere ELIAS (1993), o tempo deve ser compreendido no contexto social onde é produzido e em interação com outros elementos da vida social.

A noção de sustentabilidade está sendo entendida numa perspectiva mais ampla, segundo a qual se pode considerar que uma sociedade seja sustentável "à medida que os processos fundamentais de produção e reprodução ecológica, social, econômica e cultural funcionem" (DIEGUES, 2000, p.91).

Ou seja, é importante frisar que a sustentabilidade é um produto multicausal:

A pressão de uso que um grupo social impõe ao meio ambiente é determinada por uma combinação de fatores de ordem territorial e geográfica (densidade populacional e condições de transporte e comunicação), econômica (orientação econômica, incluindo as tecnologias de exploração dos recursos naturais, e dependência em relação ao mercado) e cultural (cultura ecológica e demandas sociais) (LIMA E POZZOBON, 2001, p.206).

\section{Tempo ecológico e práticas produtivas}

Na ilha de Paquetá e, mais especificamente, no igarapé Jamaci, como na maioria das áreas de várzea na Amazônia, estudadas por outros pesquisadores como: CONCEIÇÃO (2001), Hiraoka (1993), LEITÃO (1997), MOREIRA (2002) e SIMONIAN (2004), há informações de que houve o trabalho com o corte da seringa. No Jamaci, além dessa atividade realizava-se também o corte de madeira para as serrarias, tirava-se lenha para panificadoras/padarias em Belém e olarias de Arapiranga (Barcarena), assim como fazia-se a extração de sementes oleaginosas,

Latitude, vol. 5, n², pp.75-109, 2011. 


\section{As (Im)Possibilidades de Sustentabilidade do Modo de Vida Ribeirinho: Estudo sobre um Grupo Social na Área Insular do Município de Belém-Pa}

principalmente a de andiroba, de ocuúba; a de pracaxi era mais para o consumo doméstico.

Os jamacienses organizam suas práticas produtivas a partir de uma combinação entre a tiragem (coleta) do açaí, a pesca de camarão, a pesca de peixe e a criação de pequenos animais, como atividades principais - uma economia mista. Segundo CASTRO (2000), esse procedimento é recorrente entre esses segmentos sociais para se garantir a reprodução do grupo:

Essa adaptação a um meio ecológico de alta complexidade realiza-se graças aos saberes acumulados sobre o território e às diferentes formas pelas quais o trabalho é realizado. Suas atividades apresentam-se complexas, pois constituem formas múltiplas de relacionamento com os recursos, e é justamente essa variedade de práticas que assegura a reprodução do grupo, possibilitando também uma construção da cultura integrada à natureza e formas apropriadas de manejo (CASTRO, 2000, p. 169).

Embora todas sejam importantes, a principal fonte de renda e alimento é o açaí, no período da safra, ou seja, no verão, atividade que passo agora a tratar.

\section{PRODUÇÃO DE AÇAÍ}

Se o açaí é o produto mais importante, pelo menos no verão (de julho a janeiro), há a necessidade de um mato (terreno, lote) para o desenvolvimento da atividade. Em todas as unidades domésticas pessoas coletam açaí, inclusive os não residentes, que permanecem com os matos principalmente por causa do produto. $\mathrm{E}$ durante a safra colocam alguém pra "tomar conta", ou seja, residir no local.

Por isso, o mato se constitui num dos elementos essenciais para a reprodução dos grupos domésticos. Mas nem sempre um mato grande, para os padrões locais, significa maior produtividade. Isso pode ser explicado pelo fato de a maioria dos açaizais não ser resultado apenas de plantações ou de um manejo mais intensivo: as árvores nasceram pela ação dos pássaros como o sabiá, o periquito, o papagaio... que exercem a função de verdadeiros semeadores, ingerindo e depois dispersando as sementes em outros locais.

A produção de açaí depende do tamanho do mato, do tratamento (manejo) que esse recebe, da composição, tamanho e densidade de outras espécies, com as quais o açaizeiro concorre/compete. Embora seja uma espécie nativa, os moradores sabem que necessita de alguns cuidados, um certo cultivo, por isso chegam a plantar árvores de açaí em áreas onde não havia.

GROSSMANN (2004), concebe a construção e utilização dos sistemas de manejo como um processo de observação empírica das práticas adotadas pelos 
produtores ao longo de gerações que habitam a região, considerando as condições naturais e a relação com o mercado.

Em todos os matos jamacienses é realizado algum tipo de manejo. O mais comum consiste na eliminação das árvores velhas/altas, tortas, com baixa produtividade e de difícil acesso. Outro consiste em desbastar as touças de açaí com um número de árvores/estipes superior a quatro ou cinco - já que se trata de uma espécie de palmeira que perfilha ou, como dizem os jamacienses, "filha muito".

Observe que, para os jamacienses, a extração do palmito não se constitui enquanto uma atividade "em si", mas é uma conseqüência da necessidade do manejo. Pois há certo consenso entre os moradores de que é melhor trabalhar com o açaí (fruto) de que com o palmito. $\mathrm{O}$ argumento é bastante racional: uma árvore/estipe produz em média cinco a seis cachos por safra, os quais podem ser destinados ao consumo ou à venda, "se derrubar tira um palmito, vende, e depois?"

Após essa modalidade de manejo, retirada das árvores mais velhas/altas e novas quando tem muitos pés na touceira, o palmito extraído é comercializado e os troncos são utilizados para construção de casas, de pontes, de chiqueiros, assoalhos anexos à residência, de mará/moirões para amarrar as embarcações... o restante da biomassa e as copas são absorvidas pelo solo.

Mas segundo os moradores, só isso não é suficiente para que se tenha um açaizal produtivo, pois esta palmeira necessita de sol, o que não é possível com a proximidade de grandes árvores de outras espécies, as quais fazem sombra ao açaizeiro. Por isso é necessária a derrubada das mesmas. Após esse procedimento é possível que a produção se estenda durante o inverno. Nesse período a quantidade de açaí não é suficiente nem mesmo para a subsistência, ou como os próprios moradores afirmam: "até para arrumar o do bebe é difícil".

É muito citado o mato de um morador que realizou a derrubada de alguns "paus grandes" para eliminar a sombra de seu açaizal, pois seu terreno é apontado pelos outros moradores como exemplo de produtividade, embora seja um dos menores. Mas isso só foi possível por causa de um projeto financiado pelo poder público municipal através da Secom (Secretaria Municipal de Economia).

No Jamaci apenas o morador referido anteriormente recebeu o financiamento. Segundo esse morador, o financiamento funcionava da seguinte forma:

Eles emprestavu um dinheiro e tinha que pagá depois, o meu saiu $R \$ 2080,00$ (dois mil e oitenta reais), pra pagá com um ano depois. Esse dinheiro podia sê pago de acordo com a possibilidade de cada um, alguns parcelaram de dez vezes, eu paguei duma vez só [...] mandei limpá, mandei derrubá uns pau grande aqui dentro, agora eu to pra renová de novo, mandá limpá, roçá e derrubá outros pau grande, que eu não mandei 


\section{As (Im)Possibilidades de Sustentabilidade do Modo de Vida Ribeirinho: Estudo sobre um Grupo Social na Área Insular do Município de Belém-Pa}

derrubá tudo, porque ia destruí o açaizal completo, que as árvore grande (pau grande) quando cai vai distruindo (RONALDO, 45 anos).

Um outro morador relata como realiza o manejo em seu açaizal:

Pra tirar as arves alta é 5 ou 6 anos, demora. Tira pra clariá (...) se for menó arranca e planta no lugar que num tem (...) quando cresce já vai sombriá né, a palha duma já dá na otra, aí num dá açaí. Muito cheio assim num dá açaí, pode dá no princípio mas com tempo ela vai ficando mais velha, aí já vai diminuindo os cachos, a copa vai ficando pequena, até morrê (...) quando tem muitas só num pé, quando ela dá já tá alta e não dá cacho grande. (ALEXANDRE, 43 anos)

Comparando as duas informações, selecionadas como representando as duas extremidades, é possível ter uma idéia da variação na realização dos tipos de manejo e/ou de intervalo de tempo para a prática do mesmo. Esta variação está relacionada à tradição familiar, à capacidade de incorporar técnicas diferentes, à disponibilidade de tempo ou mão-de-obra devido à composição da unidade doméstica ou ainda de recursos financeiros. E, principalmente, ao que BOURDIEU (1979), ao estudar os camponeses argelinos, chamou de disposições econômicas e temporais.

\section{PESCAS}

O sistema jamaciense de classificação das realidades está organizado em pares, tais como: inverno e verão, quebra e lance, "buiado" e fundo, enchente e vazante, graúdo e miúdo, remanso e correnteza...

Assim, a designação beira está relacionada à questão espacial, tomando como referência à ilha de Paquetá. "Da beira, porque é aqui mesmo, na beira". É uma relação de paridade ou de oposição - beira e fora. Porém, num sentido mais restrito "beira" significa margem e por isso, alguns classificam a pesca em três categorias: "de fora, da beira e do igarapé", embora esses espaços/ambientes estejam integrados e alguns instrumentos sejam utilizados na "beira e no igarapé; na beira e fora".

Entre os moradores mais idosos do Jamaci é muito recorrente a referência a um tempo de fartura em comparação com o tempo atual, numa relação análoga a encontrada na análise de NASCIMENTO (1993), onde os pescadores do Município de Maracanã-PA relacionam o tempo de antes com o tempo da fartura e o tempo atual com o tempo da famitura; Essa mesma referência é relatada por LEITÃO (1997), ao mencionar a lembrança de muita fartura, na memória dos pescadores da Ilha do Capim no estuário amazônico; Essa relação também é analisada por 
João Luiz da Silva Lopes

VILHENA (2005), na perspectiva das estratégias de adaptabilidade humana a um contexto de escassez no estuário amazônico.

A pesca no igarapé visa apenas o autoconsumo, exceto a de camarão que atualmente é destinada principalmente para a comercialização.

\section{Pesca de Camarão}

Se no verão a atividade principal é o açaí, no inverno (de dezembro a junho) é a pesca, principalmente a de camarão. Segundo alguns moradores do Jamaci até o mês de maio é que aparecem os camarões graúdos, depois é só miúdo.

A técnica utilizada na pesca do camarão é a do matapi, instrumento confeccionado com tala de jupati (palmeira típica da região) ou garrafas plásticas (pet), colocados no igarapé presos por um fio ou cipó a uma vara, galho ou raiz de árvores.

Os matapis geralmente são confeccionados pelos próprios pescadores, são poucos os que compram ou muitas vezes compram para completar os confeccionados ou recuperados do ano anterior.

Tanto a tala como o matapi novo precisam ser colocados para apanhar sol, porque a tala em contato com a água produz uma "gosma que fede muito, aí o camarão não entra". Ou seja, trata-se de uma espécie de limo cujo odor afasta o camarão.

O tempo de durabilidade de um matapi de tala de jupati com cipó ou fio plástico, sendo este último de recente introdução e o cipó é comprado porque não há nos matos locais, é de uma invernada. Quando é tirado da água e colocado em lugar que não apanhe chuva pode ser reformado (trocando-se as talas apodrecidas e ajustando a amarração) e reutilizado. O matapi feito de garrafas plásticas dura mais ou menos cinco anos, que é o tempo da invenção e introdução pelos moradores no local.

Alguns resistem e preferem o matapi de tala porque não pega camarão muito miúdo, pois as frestas entre as talas permitem que saiam e o de plástico não. Além disso, não é preciso comprar talas, estas são coletadas, "tirada no mato", como se diz na linguagem local. Outros preferem as garrafas porque são mais resistentes e não deixam entrar muita sujeira, como no de tala, apenas camarão. Mas geralmente usam uma parte de tala e outra de plástico.

Além do igarapé maior (Jamaci), são utilizados os pequenos igarapés que se desmembram do mesmo, nos quais só é possível despescar os matapis com a maré grande (cheia), a menos que se pise na lama ao invés de usar a canoa. Esta situação geralmente ocorre de manhã sedo, quando os matapis não são despescados à noite, por causa dos guaxinins (Procyon cancrivorus), um animal não domesticado, que segundo os moradores é parecido com um cachorro, que quebra os matapis para comer os camarões. No momento da despescagem também se coloca a isca que serve para atrair os camarões ao interior do matapi. A isca utilizada é o fruto moído da

Latitude, vol. 5, n², pp.75-109, 2011. 


\section{As (Im)Possibilidades de Sustentabilidade do Modo de Vida Ribeirinho: Estudo sobre um Grupo Social na Área Insular do Município de Belém-Pa}

palmeira babaçu, uma espécie de farinha comprada em casas comerciais de Icoaraci. A essa farinha se adiciona água para aumentar o volume, acentuar o odor e adquirir consistência para ser arrumada. Essa mistura é embalada, em pequenas porções, em folhas de guarumã ${ }^{3}$, amarradas com folha murcha de açaizeiro ou de miriti extraídas assim que começam a abrir.

Essas pequenas embalagens são chamadas de "poquecas". Depois de prontas sofrem um pequeno corte de tesoura ou faca para permitir o acesso dos camarões atraídos pelo cheiro da isca. Geralmente, a "despescagem" dos matapis, em torno de 30 a 40 por unidade doméstica, ocorre uma ou duas vezes durante o dia, considerando as 24 horas que é o tempo em que a maré enche e vaza duas vezes.

Uma outra modalidade, menos usada, é não colocar isopor permitindo que o matapi afunde até o leito do igarapé ou praia; segundo os adeptos desta técnica, "o camarão dá mais graúdo". Esta pode ser realizada no igarapé, foz e/ou praia/rio. E a "despescagem" ocorre com a maré bem baixa, um pouco antes da enchente.

A tarrafa também se constitui numa técnica utilizada, geralmente à noite na praia. Esta é destinada a pegar só os camarões graúdos.

Após a "despescagem" os camarões são armazenados no "viveiro". O viveiro é mais ou menos parecido com o matapi, só que maior e sem aberturas nas extremidades, e sim na lateral. Este equipamento é mantido no igarapé próximo da casa para que os camarões permaneçam vivos até o momento da comercialização.

No momento da comercialização, o camarão vivo é mais valorizado, é como se fosse uma garantia ao comprador, uma evidência disso é o fato de se perder a preferência e diminuir o valor do produto se for encontrado algum camarão morto pelo meio. Por isso, ao se aproximarem do trapiche de Icoaraci, quando já está mais claro o dia, os pescadores começam a catar os mortos/podres. Da mesma forma, o camarão "frito" é menos preferido, porque pressupõe que estes não estavam em boas condições - vivos. As mortes são causadas pelas más condições de conservação. Por exemplo, o "viveiro" muito cheio ou quando a maré está de "quebra" (sem muita força; água com pouco movimento), possibilitando o aquecimento da mesma. E, como o viveiro fica na superfície, com a água aquecida os camarões morrem.

Pesca da Beira

A "pesca da beira" é realizada próximo da ilha, com ou sem a utilização de canoa motorizada tanto no verão quanto no inverno, dependendo do pescador. Pois alguns não realizam a pesca de fora e os que realizam não o fazem o tempo todo, sendo possível, portanto, combinar as duas.

3 Guarumã é uma espécie de vegetal que tem as folhas largas, cujo caule é utilizado como tala para fazer paneiro, tipiti, peneira... 
Dependendo da quantidade, os peixes são destinados para o autoconsumo e para a comercialização; mas, o objetivo maior é o primeiro.

Pesca de Fora

A "pesca de fora" é realizada, principalmente, no inverno. O termo fora caracteriza a maior distância e o maior tempo que se leva de casa até o local da pesca.

Essa pescaria é considerada "um pouco arriscada por causa do vento". Um outro tipo de risco que foi relatado por um ex-morador do Jamaci (hoje residente na ilha de Cotijuba) é a ação dos piratas ou ratos d'água muito arriscada, por causa de alagamento e por causa dos ratos d'água. Eles caparam meu primo, jogaram na água pra robarem o barco, ele e o outro (pescador) morreram afogados. Depois acharam os corpos" (PAULINO MACHADO, 50 anos).

Outro pescador complementa:

A pesca de fora é mais arriscada né, por causa que a gente se aventura mais. Vamos dizer assim; tu sai pra fora né, ai o mar tá calmo, chega lá ele fica brabo, aí às vezes a canoa é pequena né. Quando não, dá um tempo, aí maresia, muita maresia, aí o cara se vê enrascado.(FRANCINALDO BAIA, 37 anos).

Para a realização dessa pescaria é necessário um bote ou canoa motorizada, que não tenha tábua podre, para poder resistir às ondas (maresia). Se o motor/máquina estiver apresentando algum indício de problema de manutenção precisa ser resolvido antes da viagem. Tem que preparar a conservadeira com gelo para acondicionar o peixe; no caso do Jamaci usam-se caixa termoisolante, utilizadas também por distribuidoras de bebidas para colocá-las no gelo. E por fim, antes de partir tem que arrumar a "despesa" e a infraestrutura, como descreve um dos pescadores envolvidos nesse tipo de pescaria:

Tem que embarcá a despesa que é, café, açúcar, sal, farinha, bolacha, comida e assim vai. É como se fosse uma casa, tem que tê tudo, carvão pra fazê o fogo, panela, tudo isso mesmo. O que a gente usa numa casa a gente usa num barco, porque a gente passa quatro dia, uma semana, às vezes até mais. (CARLINHOS, 28 anos).

Essa modalidade de pesca é mais dispendiosa, necessita de um investimento maior, pois implica a aquisição de óleo diesel e lubrificante para o motor, bateria

4 Para maiores informações sobre este assunto, ver SILVA, Maria José. Parceria e Pirataria: uma abordagem etnográfica para novos estudos sobre a dinâmica da pesca na Amazônia. Dissertação (Mestrado em Sociologia) - Universidade Federal do Pará. Belém, 2005.

Latitude, vol. 5, n², pp.75-109, 2011. 


\section{As (Im)Possibilidades de Sustentabilidade do Modo de Vida Ribeirinho: Estudo sobre um Grupo Social na Área Insular do Município de Belém-Pa}

de carro e lâmpada (fonte de energia), o rancho (farinha, açúcar, café, comida...), gelo e sal para armazenar o peixe até à volta e muita disposição para enfrentar sol, chuva, vento, frio, sono e eventuais acidentes, além da possibilidade de retornar sem peixe algum, sem "arrumar" nada. Apesar de um dos pescadores afirmar que "meno (ao menos) pra comer a gente pega" (COSME COSTA, 42 anos). Outro complementa: "a pescaria de fora é uma aventura, às vezes só pega da bóia (para o consumo dos pescadores e família)" (DÁRIO, 45 anos).

Algumas vezes este investimento é feito pelo patrão, como relata outro pescador: "a gente tem patrão certo em Icoaraci, quando a gente não tem dinheiro, ele arranja pra comprá o óleo, às vez pro gelo, pra fazer o rancho" (JOVENTINO, 56 anos).

\section{CRIAÇÃO DE PEQUENOS ANIMAIS}

A prática de criar pequenos animais, como galinha, pato e porco, é muito comum e importante para os moradores de Várzea, porque complementam o sistema de reprodução, tanto na dieta, quanto na renda dessas famílias.

\section{O ideal do real}

Embora muitos digam, "no verão é o açaí e no inverno é o camarão", isso não significa, necessariamente, que uma atividade substitua a outra totalmente. Em alguns casos vão se alternando enquanto atividade mais importante em cada período/estação. "No verão é o açaí" significa dizer que este é destinado ao consumo e à comercialização; já o camarão é destinado ao consumo doméstico, mas também é comercializado, apesar da pesca ser menos intensa nesse período, ocorrendo somente durante o dia e com uma quantidade menor de matapis. "No inverno é o camarão", para comercialização e consumo, nas marés do dia e da noite, com uma quantidade maior de matapis, enquanto o açaí atende precariamente ao consumo doméstico. Mas se alguém consegue apanhar o suficiente para encher uma rasa é preferível vender, porque o preço compensa. "Mas tem inverno que não dá um cacho pra beber" (MANOEL MARIA, 56 anos).

Na perspectiva do ideal, durante o verão os matapis devem ser tirados da água, porque "se ficarem na água o tempo todo cansa o igarapé e aí não pega mais nada". Essa regra social funciona enquanto discurso, mas na prática há manipulações.

A integração ao mercado acaba influenciando o calendário de atividades e a relação com o meio ambiente. Mas essa alteração não abrange a todos e nem da mesma forma. Está relacionada a uma série de fatores, como o tamanho do grupo doméstico, a existência ou não de outras atividades complementares, a tradição familiar de manejo e uso dos recursos naturais...

A pesca de camarão é orientada também por uma combinação com os ciclos da maré, que são chamados de "lançante e quebra", os quais estão relacionados às 
João Luiz da Silva Lopes

fases da lua. As marés lançantes são as maiores, portanto possuem um volume maior de água e dificultam a pesca de camarão porque "a maré corre muito e a boca do matapi fica tapada de folha, o matapi não para pro camarão entra" (COSME COSTA, 43 anos). Nesses momentos, geralmente tiram os matapis da água e colocam para secar ao sol. Mas numa das visitas a campo, percebi que alguns moradores continuavam a pescar, mesmo nesses momentos.

Por isso cabe questionar: será que essas atitudes estão relacionadas a uma suposta consciência ecológica ou às dificuldades na realização da atividade? $\mathrm{Ou}$ trata-se de orientações relacionadas às tradições familiares, portanto, diferenciadas de acordo com cada grupo?

No discurso quase todos se dizem preocupados com a renovação dos recursos naturais, afirmando que soltam os camarões pequenos ou que colocam no viveiro e eles saem, mas uma observação mais atenta possibilita constatar que há manipulações, pois a maioria dos moradores consome e comercializa camarões e peixes pequenos, mesmo no período de reprodução.

Possivelmente esse discurso foi coerente com a prática em um passado não muito distante, no "tempo dos antigos" quando era possível pegar muito e graúdo. Um dos informantes relata que seu avô tinha apenas oito matapis e pegava mais ou menos 17 (dezessete) quilos por dia. Atualmente o filho desse mesmo informante diz que tem 45 (quarenta e cinco) matapis e leva 2 (dois) dias para pegar uma média de 6 (seis) quilos. (ALEXANDRE, 43 anos e AILTON, 23 anos).

Os dados mostram que realmente há captura, consumo e comercialização de camarão no período de reprodução, mas isso deve ser relativizado pelo fato de que, segundo COLLART (1993), o camarão canela (Macrobrachiun amazonicum) apresenta uma época de reprodução sazonal bem marcada com desovas maciças nos meses de maio e junho, mas durante os outros meses também ocorrem desovas. Isso significa dizer que há reprodução durante o ano todo.

Em relação à consonância do tempo ecológico com a realização da pesca, $o$ ideal, entendido na concepção de GODELIER (1981), era que essa atividade fosse praticada durante o inverno e nas marés de quebra, mas como se vê há os que pescam durante o verão e nas marés lançantes. Mas os que pescam no período do verão e nas marés lançantes diminuem a quantidade de matapis e a intensidade da atividade. Neste sentido, pode-se considerar que o tempo ecológico exerce grande influência no ritmo dessa prática.

A produção do camarão é destinada à comercialização, principalmente no inverno, período em que não há açaí para comercializar. Mas é mais coerente dizer que há uma divisão contextual ou conjuntural entre o consumo doméstico e a comercialização, isto é, de acordo com a quantidade e com a necessidade.

No período do inverno há uma estratégia quanto à quantidade de matapis utilizada, que consiste em arriar todos quando há maior ocorrência, no dizer dos pescadores: "quando tá dando muito camarão" e deixar só uma parte na água, quando 


\section{As (Im)Possibilidades de Sustentabilidade do Modo de Vida Ribeirinho: Estudo sobre um Grupo Social na Área Insular do Município de Belém-Pa}

diminui a ocorrência. Uma lógica meio inversa à lógica do mercado, a qual pode ser explicada pelo fato de que se evita desperdiçar esforço e isca com muitos matapis, sem o devido retorno.

Outro elemento interessante é a distinção entre as técnicas de pesca antigas e as atuais realizadas no igarapé, enfatizando que as últimas, rede de lancear, rede malhadeira e a tarrafa, são mais eficientes. Porém, essas técnicas são criticadas por alguns moradores, principalmente pelos mais antigos; porque "cansam o igarapé" ou "espantam os peixes". Mesmo os que admitem e praticam entendem que as mesmas não devem ser intensas.

\section{A vida na confluência das lógicas de trocas}

Muitos trabalhos que procuraram analisar a situação de pequenos agrupamentos foram realizados a partir de orientações evolucionistas, funcionalistas ou estruturalistas, conforme advertem BALANDIER (1969) e CLASTRES (1990), fortemente marcadas pela perspectiva de um movimento de fora pra dentro, de tendência homogeneizante, sem espaço para o diferente, para a diversidade, para o hibridismo.

O exercício que fiz com o presente trabalho pretendeu ir em sentido contrário, procurando superar a idéia que concebe a situação do segmento social estudado como simples efeito ou reflexo da penetração do capitalismo no meio rural/ribeirinho, para ressaltar a interação entre a lógica econômica dos ribeirinhos e a lógica econômica capitalista dominante.

Destarte, pressuponho que não se deve pensar as práticas, os valores e o sistema de trocas do mundo moderno/capitalista como algo partilhado por todos de forma padronizada, como categoria universal, independente das condições ambientais, econômicas e sociais específicas, nas quais são tecidas as redes de sociabilidade que sustentam a existência de diferentes coletivos. Há uma enorme complexidade nessa trama de relação e interações, como explicitado no conceito de habitus:

Em resumo, se alguma propriedade universal existe, é a de que os agentes não são universais porque as suas características, e em particular as suas preferências e os seus gostos, são o resultado da sua posição e deslocações no espaço social, como tal da história coletiva e individual. A conduta econômica socialmente reconhecida como racional é o produto de determinadas condições econômicas e sociais (BOURDIEU, 2006, p. 290-291).

Desse modo, as práticas econômicas dos moradores do Jamaci devem ser analisadas e compreendidas considerando-se também categorias que compõem sua 
consciência temporal. Neste caso, as referências temporal e espacial estão relacionadas, em grande parte, a um contexto específico. Este estado ou contexto retrata uma situação recorrente na Amazônia ribeirinha, onde a organização social da produção durante o inverno gira em torno da pesca de camarão e a pesca (de fora) de peixe, realizadas especialmente pelos homens; na pesca do camarão, a quantidade de matapis pertence à unidade doméstica e não uma determinada quantidade a cada integrante da mesma; no verão essa atividade é praticamente interrompida dando vez à coleta do açaí, cujo processo é realizado pelos próprios moradores.

Atualmente os caboclos ribeirinhos e, mais especificamente, os jamacienses, continuam a se reproduzir nas franjas dos processos econômicos dominantes. MAUÉS e MOTTA-MAUÉS (1999), ao analisarem o processo de integração de uma comunidade rural (insular) de pequenos produtores à economia capitalista, relatam que estes desenvolvem uma estratégia que combina o auto-consumo e a comercialização, a qual, por um lado, obriga o produtor a participar de uma economia de mercado, e por outro, não permite que permaneça inteiramente a mercê desse mercado, conferindo certo grau de autonomia ao seu sistema produtivo.

Um aspecto relevante que possibilita essa estratégia é a existência de uma economia mista, ou seja, da combinação de várias atividades, principalmente a coleta do açaí, a pesca de camarão, a pesca de peixe e a criação de pequenos animais. O rendimento de parte do produto que é comercializado não é destinado à cumulação de capital, mas sim à compra dos bens que necessitam para a reprodução, que não são produzidos no local, como a farinha de mandioca, açúcar, sal, pão, arroz, feijão, óleo diesel/ querosene para as lamparinas (energia) e motores de embarcação, assim como para a confecção e manutenção de instrumentos de pesca e das próprias embarcações e para a compra de roupas, calçados e outros.

Os jamacienses são os proprietários de seus meios de trabalho e não estão sujeitos a submissão por dívida, nem ao controle de intermediários, situação favorecida pela proximidade de um grande centro, onde podem comprar e vender seus produtos, a cidade de Belém.

Os jamacienses possuem uma lógica diferente da lógica que orienta o mercado capitalista e, por isso, a maioria deles não aceitou as propostas de financiamento, tanto para pesca quanto para o manejo do açaí (para este apenas um morador aceitou). Essa atitude em relação ao crédito/financiamento pode ser compreendida com auxílio de BOURDIEU (1979), ao analisar a sociedade argelina, quando diz que o crédito possui uma lógica estranha à economia pré-capitalista, pela referência a um futuro abstrato, definição por um contrato escrito, pela impessoalidade das relações entre os contratantes e garantia de pagamento por todo um sistema de sanções.

Latitude, vol. 5, n², pp.75-109, 2011. 


\section{As (Im)Possibilidades de Sustentabilidade do Modo de Vida Ribeirinho: Estudo sobre um Grupo Social na Área Insular do Município de Belém-Pa}

Essas relações parecem aos Jamacienses meio esquisitas, porque a escrita, a formalidade, as impessoalidades não fazem parte do universo social da maioria deles. Mas isso não significa dizer, como na situação interpretada por BOURDIEU (1979), que haja uma restrição sistemática no campo das aspirações de forma a excluir metodicamente as situações insólitas que exigiriam a criação de novos esquemas. Pois há iniciativas nesse sentido, vale ressaltar o caso de uma unidade doméstica que começa a se diferenciar das outras: dois membros da mesma possuem uma renda proveniente de outras atividades.

Todas as unidades domésticas jamacienses necessitam estabelecer relações comerciais com o exterior, a fim de garantir sua reprodução bio-sociocultural. Mas, o tempo da comercialização é diferente do tempo da produção: pois a realização de atividades, como coletar açaí, pescar camarão, peixe (na beira e fora), ocorrem em consonância com o tempo ecológico, ao passo que a comercialização tem um horário fixo estabelecido pelo tempo mecânico. E, há indícios de que essas relações estão influenciando as práticas locais como, por exemplo, a pesca do camarão no verão, segundo depoimento de uma moradora:

Antigamente pescava só no inverno, agora o camarada pesca inverno e verão, todo o tempo ele tem camarão. Quando chegava o verão todo mundo suspendia o matapi, por causa do açaí né, agora não, pode ter açaí, mas o matapi tá na água sempre [...] é porque, quando é assim no verão, o camarão fica bom de vendê, porque no inverno dá muito camarão, às vezes dá tampa (grande quantidade) de camarão em Icoaraci, aí o pessual quere comprá barato (DONA ESTER, 84 anos).

Mas, é importante enfatizar que os jamacienses também manipulam alguns elementos buscando auto-favorecimento. Há três exemplos, relacionados à comercialização do açaí, que são bastante ilustrativos: 1) os moradores sabem que os compradores (maquineiros ou batedores) consideram o melhor açaí aquele "tuíra", como chamam os trabalhadores do ramo (de cor cinzenta), e para atender essa exigência os jamacienses utilizam a estratégia de colocar o açaí nessa condição no fundo e na parte superior da rasa; 2) No apogeu da safra, quando há grande oferta de açaí na feira, os preços baixam e alguns produtores preferem retornar com a fruta, misturar a outra, para que os compradores não percebam, e vender no dia seguinte (é o famoso açaí muquiado); 3) como os jamacienses sabem que a quantidade do açaí no final da safra diminui bastante, como estratégia utilizam rasas menores que as usadas nos outros períodos da safra.

Outra iniciativa de manipulação é a realização de manejos de açaizais visando o aumento da produção. Mas, em ambos os casos essas mudanças são cautelosas. No primeiro caso, os que pescam camarão durante o verão, pescam 
com uma quantidade de matapis menor e com menos intensidade que no inverno, realizando a pesca só na maré do dia, isto é, não iscam e nem despescam à noite. No segundo caso, apenas um morador realizou um tipo de manejo mais racional /intensivo por causa do financiamento que recebeu, dada sua condição econômica e social.

A condição econômica e social pode funcionar como um freio ou desencorajamento para os demais. Porque, se por um lado, aumenta a produção, por outro lado, é preciso pagar o empréstimo. Esse pagamento se torna inviável, por conta das despesas domésticas, ou seja, os bens básicos para a reprodução que durante o verão passa a ser custeada pela renda obtida com a venda do açaí. Além disso, o preço do açaí baixa nesse período, principalmente no auge da safra, devido à quantidade ofertada, e o valor do financiamento a ser pago não está condicionado ao preço do produto. Então não há garantia de pagamento se não houver outras fontes de renda.

Outra estratégia é que, embora as famílias se dividam em termos de residência/casa, as despesas (consumo) são realizadas em conjunto, como ilustra a fala de uma moradora: "A gente mora separado, mas a despesa é tudo junto" (DONA NAZARÉ, 56 anos).

Há um movimento estratégico, no sentido de aproximação e utilização de elementos relacionados à consciência temporal "moderna" ou do mercado quando é conveniente e de distanciamento ou rejeição desses elementos quando a situação é desfavorável.

As técnicas mais "modernas" algumas vezes são parcialmente incorporadas, sofrem adaptações ou (re)criações, outra vezes são rejeitadas.

Pode-se considerar que de acordo com o grau de integração à lógica da economia capitalista e a necessidade econômica, varia o grau de tensão com as "normas tradicionais" que orientam o período de realização de cada atividade, isto é, entre as disposições econômicas e temporais:

Deste modo, a necessidade econômica pode impor aos mais desfavorecidos condutas nas quais pode-se ver o cumprimento assim como a transgressão da tradição. Essas condutas não tomam sentido verdadeiramente nem em relação à lógica tradicional nem em relação àquela da economia capitalista. Na realidade, tal como uma gestalt ambígua, cada conduta pode formar o objeto de uma dupla leitura pois ela traz em si própria a referência às duas lógicas impostas pela necessidade (BOURDIEU, 1979, p.76).

Em que pesem as mudanças e os reajustes causados pela tensão entre as lógicas temporais e econômicas, é possível observar uma organização coerente do 


\section{As (Im)Possibilidades de Sustentabilidade do Modo de Vida Ribeirinho: Estudo sobre um Grupo Social na Área Insular do Município de Belém-Pa}

tempo com um sistema de relações e expectativas concretas. Em outras palavras, permanecem vivos os pontos de referências que orientam os quadros temporais e espaciais, nos quais se desenrola a existência, garantida pela reprodução das práticas que permanecem sem muitas perturbações em suas essências.

\section{Dança nos Espaços-Tempos}

A situação ribeirinha torna-se possível também pelo fato de haver um fluxo de saída de moradores. É como se houvesse certa convenção local: nossa lógica é essa, nosso ritmo é esse! Quem não aceita deve procurar outros lugares.

A saída de moradores funciona como um mecanismo de controle da densidade demográfica. Porque caso todos os nascidos no Jamaci permanecessem lá, não seria possível a reprodução como ocorre atualmente. Com isso, não queremos dizer que a questão demográfica é determinante, pois aí estaríamos contradizendo a perspectiva desta reflexão que é o questionamento de análises simplistas, reducionistas e/ou deterministas.

São vários os motivos, como veremos a seguir, pelos quais as pessoas saem do Jamaci em direção a outros locais. Dentre os quais destacamos a Ilha de Cotijuba, onde entrevistamos algumas delas. Veja o que dizem:

Eu nasci e me criei no Jamaci, antes (quando era novo) tinha fartura de peixe, açaí, camarão e agora não tem mais, antes tinha mais gente e tinha mais fartura. Ali não presta mais, já foi bom lá, agora não tem mais nada [...] nada se pode fazer, só Deus, a menos que seja uma técnica de plantio [...] vi muita gente se acabar lá, porque não tinha motor, antes era só no remo. Vi muita mulher grávida morrer durante o parto, acidente, queda de açaizeiro, doenças. Que futuro tem ali? Nada. Apanhador de açaí, que profissão é essa? Lá não tinha como dar um futuro pro meu filho, agora tou trabalhando para dar um futuro melhor pra ele. Chegou pra cá, tem muita coisa pra trabalhar, ganhar dinheiro, ir para Icoaraci/Belém a hora que quiser, $90 \%$ melhor por tudo: posto médico, aqui tem colégio (escola) dia e noite para os filhos estudarem, tem rua. Lá saiu de casa tá na lama, só no verão que melhora um pouco por causa do açaí. Daqui com mais alguns anos não vai ficar ninguém lá, só tão os galinhos (os mais novos) a maior parte já tão comprando terreno aqui (Cotijuba), muita gente já se mudou pra Icoaraci, Outeiro. Lá só mora as pessoas que não tem condições de sair. Um terreno aqui (Cotijuba) é $\mathrm{R} \$ 700,00$ reais, como vão arrumar (esse dinheiro), se o que 
arrumam só dá pra comer e mal? (PAULINHO MACHADO, ex-morador do Jamaci, 58 anos).

Vamos tentar compreender o sentido/significado desse discurso. Este senhor passou boa parte da vida realizando atividades diferentes dos demais moradores: nas décadas de 70 e 80 trabalhou durante 10 anos em uma companhia de pesca industrial; ao sair da mesma comprou um barco para pescar.

Em 1997 e 1998 trabalhou como barqueiro, prestando serviço à Escola Bosque; em 2002 vendeu o terreno do Jamaci e comprou um lote urbano na Ilha de Cotijuba, onde reside atualmente com a esposa e um filho. Seu depoimento exalta o modo de vida atual e julga inferior o modo de vida dos jamacienses. Mas, analisando a condição em que vive atualmente, apesar de dizer que melhorou $90 \%$ em tudo, pode-se considerar que não é tão diferente da anterior: o lote que comprou em Cotijuba é relativamente longe do local onde estão certos 'atrativos' urbanos (trapiche, unidade de saúde, escolas...); o acesso ao local onde reside se faz por um caminho, que no momento da pesquisa encontrava-se praticamente intrafegável pela quantidade de mato; a casa que construiu, onde aprendeu a atividade de carpinteiro na qual atua como "bico", é de madeira, com assoalho alto tipo palafita, mesmo estilo das casas do Jamaci; como a casa que comprou fica longe da beira da água onde deixava o barco, teve que vendê-lo porque tentaram roubar, o que tornou inviável até mesmo a atividade da pescaria, além disso, diferentemente de como acontece no Jamaci, em Cotijuba, pelo menos na parte em que reside, o peixe, o camarão e o açaí são adquiridos com dinheiro, isto é, comprado.

Ao ser questionado sobre a possibilidade de voltar para o Jamaci, afirmou categoricamente que não voltaria e repetiu todos os aspectos que o mesmo destacou como negativos nesse igarapé. Mas, a saída do Jamaci pode também, estar relacionada à (des)integração das relações sociais de parentesco, pois seu pai faleceu em 2000 e sua esposa não tinha parentes no local.

Em 2003, os integrantes de uma outra unidade doméstica mudaram-se para Cotijuba. Inicialmente alugaram uma casinha, depois fizeram um empréstimo ao Banco do povo ${ }^{5}$ e compraram um terreno com uma casa na rua principal, próximo ao trapiche. A moradia em Cotijuba é encarada como:

Um esforço para os filhos estudarem, às vezes vinham sem almoçar, apanhavam chuva, demoravam voltar. É muita vontade pra estudar, porque é muito sacrifício [...]

${ }^{5}$ Banco do Povo: uma instituição de microcrédito da Secretaria Municipal de Economia do município de Belém (SECOM), que teve início em 1998, na Administração do Prefeito Edmilson Rodrigues (PT), com o objetivo de combater a pobreza e o desemprego no município.

Latitude, vol. 5, n², pp.75-109, 2011. 


\section{As (Im)Possibilidades de Sustentabilidade do Modo de Vida Ribeirinho: Estudo sobre um Grupo Social na Área Insular do Município de Belém-Pa}

Aqui ficou mais perto de tudo, a ilha cresce com futuro: já tem escola, posto médico, telefone, energia. O desenvolvimento vai chegando e a gente vai trabalhando. [...] lá é sossegado, é calmo, mais o trabalho é mais pesado, tem que trabalhar se não passa fome. Aqui é barulhento, final de semana é barra pesada. No Jamaci é bom, tenho vontade de preservar (NELDMAR MARTINS, 45 anos).

Questionado sobre a possibilidade de retornar para a antiga morada, um integrante dessa unidade doméstica respondeu que:

Assim que os filhos se formarem, porque lá é calmo, é lugar pra velho, pra envelhecer. Mas quando for, vou levar um gerador de energia. (NELDMAR MARTINS, 45 anos).

No Jamaci viviam do açaí, da pesca de camarão e peixe, tinham barco e, detalhe importante, na época da borracha, era ele quem negociava toda a produção da mesma no local e vendia para um primo, que vendia para outro parente, o qual finalmente repassava para a Pirelli, a média de duas toneladas por semana. Provavelmente a atividade proporcionou um contato com a calculabilidade e uma lógica temporal diferenciada. Talvez a idéia de desenvolvimento, crescimento, futuro seja resultante desse período.

Atualmente o casal trabalha com um pequeno comércio, uma máquina de beneficiar açaí (coletado no terreno do Jamaci), o marido pesca no barco e representa na ilha a Igreja do Evangelho Quadrangular. Quando o marido sai é a esposa quem assume o comércio e o açaí, além das atividades domésticas, como ocorria no Jamaci quando era ela quem cuidava dos matapis quando ele viajava.

Uma das pessoas integrantes de outra unidade doméstica, que se mudou para Cotijuba no início de 2004, revela os motivos:

Por causa da filha que estudava aqui (em Cotijuba), saía cedo e não tinha hora pra voltar, lá não tem trabalho, o ganho é pouco, não tem escola, não tem água boa pra beber [...] Aqui tem escola, tem médico, não tem que remar, tem barco pra Icoaraci a hora que quiser. Lá até que é bom de morá, mas é muito atrasado. Quem mora lá não tem futuro, nem com os filhos (DUCILENE MARTINS, ex-moradora do Jamaci).

Estas pessoas não venderam o terreno localizado no Jamaci, apenas desmanchou a casa para reformar a outra que foi comprada na ilha de Cotijuba, 
onde trabalham com comércio pequeno, máquina de beneficiar açaí e a mulher revende produtos da Avon, Racco e bijuterias. Além disso, cuida da mãe aposentada.

Na época da safra, o açaí beneficiado é originário do terreno que deixaram no Jamaci. Questionados sobre a possibilidade de retornar para o Jamaci, a resposta foi: "nem pensar".

Observei que quando moravam no Jamaci, além das atividades do marido com açaí, peixe e camarão, a mulher já revendia produtos da Avon e Bijuterias. Uma atividade diferente que envolve diretamente uma outra racionalidade, a calculabilidade. Sua clientela era pequena e precisava aumentar para expandir os rendimentos, por isso também o local se tornou inviável para morar e desenvolver esta atividade.

Os integrantes da quarta unidade doméstica migraram para Cotijuba no início de 2005, por que:

[...]O meio de vida é muito cruel, muita dificuldade para estudar. Aqui a gente passa alguma dificuldade, trabalha só com essa mercadoriazinha e não tem emprego. É um esforço para as filhas estudarem, saiam cedo, sem almoçar, às vezes sem comer; chegavam de noite, por baixo de temporal. A gente qué a melhoria dos filhos, tem que trabalhar, batalhar pra ajudar eles (DINALVO MARTINS, 38 anos).

Na comparação entre os dois lugares ele (o marido) continua e diz:

Eu gostava muito de lá, era sossegado, não tinha zoada, carapanã, calor, dava pra dormir. Agora tá muito ruim por causa de ladrão (DINALVO MARTINS, 38 anos).

E a mulher se pronuncia dizendo:

Melhor é aqui por causa do ensino, tem posto de saúde bem aqui, água encanada. Aqui é mais fácil, mais tranqüilo, é melhor pra viver. (ROSA DIAS, 35 anos).

Questionados sobre a possibilidade de retorno para o Jamaci, o marido responde: "estamos fazendo um teste aqui, vendo se consegue comprar uma casa, por que essa é alugada". Embora a mulher não tenha se pronunciado neste momento, na declaração anterior manifestara a sua preferência em permanecer na ilha de Cotijuba, onde mora sua família (pais e irmãos).

Observe a grande diferença entre esse e o primeiro caso. Pois este reconhece as dificuldades enfrentadas em Cotijuba: casa alugada, falta de emprego e vivendo de um pequeno comércio e uma máquina de beneficiar açaí, proveniente da parte 


\section{As (Im)Possibilidades de Sustentabilidade do Modo de Vida Ribeirinho: Estudo sobre um Grupo Social na Área Insular do Município de Belém-Pa}

do terreno herdado, porque do terreno que adquiriu por compra, derrubou os açaizeiros para tirar palmito e plantar novas mudas para aumentar a produtividade. Já está informado de que na Empresa Brasileira de Pesquisa Agropecuária (Embrapa) custa um real cada muda: trata-se de um projeto bem diferente, um plantio racional que visa aumentar a produtividade.

É possível observar certa seqüência na saída das mesmas do Jamaci para Cotijuba. No novo local não moram muito próximo um dos outros, o que pode ser explicado pela natureza das atividades que realizam - comércio e venda de açaí devido à concorrência. Mas procuram se ajudar, na medida do possível como, por exemplo, o que possui o barco vai comprar carvão na ilha de Arapiranga para ele, para o irmão e para a irmã venderem.

Seja por considerarem a crueldade do meio de vida e o futuro dos filhos, que aparece como esforço principalmente em relação à educação, seja por emitirem apreciações/juízos sobre os modos de vida nos diferentes locais, o fato é que essas pessoas saem do Jamaci para outro lugar mais "adiantado" ou "desenvolvido" se desconectando dos quadros de referência temporal e espacial anteriores. Mudança que tende a se intensificar com a implantação de energia elétrica já em funcionamento na ilha de Cotijuba.

Analisando a comparação feita pelos migrantes sobre os dois lugares, é possível perceber certo menosprezo pelo Jamaci, por causa do meio de vida, da falta de escola, posto médico, transporte, desenvolvimento; "quem mora lá não tem futuro"; "só mora lá quem não tem condições de sair", etc. Mas, não se pode ignorar alguns aspectos positivos como: lá é calmo, não tem barulho, não tem carapanã, ladrão, dá para dormir tranqüilo, etc. Há uma certa tensão e/ou contradição entre os dois ritmos temporais, isto é, mesmo os que resolveram sair do Jamaci não deixam de reconhecer que, em alguns aspectos, lá é melhor do que em Cotijuba.

E, passando a analisar de dentro da comunidade, isto é, do ponto de vista dos que permanecem no local, esse sentimento é ainda maior. É possível perceber que há uma insistência em defender/proteger um conjunto de normas e valores econômicos, culturais e sociais que os jamacienses associam a sua permanência no local, ao acesso e gestão de recursos naturais existentes.

A permanência ou não do estilo de vida jamaciense está relacionada a uma situação mais ampla que é: como conviver com o mercado, com o mundo "moderno", com o tempo mecânico que tentam destruir ou homogeneizar esse conjunto de valores e normas?

É verdade que não se pode ignorar a influência das políticas de Estado (poder público) e da iniciativa privada (capital) implementando, por exemplo, o projeto de desenvolvimento da pesca (pesca industrial), incentivando um modelo de pesca predatório (LOUREIRO, 1985). A essas forças que perturbam seu ritmo de vida, os Jamacienses são obrigados a se adaptar. 
A convivência dos jamacienses com o mundo "moderno" é facilitada pela proximidade geográfica com as ilhas de Cotijuba e Caratateua (mais conectados com o modo de vida urbano) e área continental do município de Belém, aonde vão constantemente comercializar seus produtos, usar os serviços de saúde, freqüentar escolas, se divertir, visitar parentes, etc. Além disso, estão conectados a esses outros universos por meio de seus rádios e televisores que funcionam com baterias de automóveis.

Essa convivência possibilita uma situação paradoxal, a qual exige uma análise complexa. Dizer que a permanência do tempo ecológico como referência temporal é apenas sobrevivência de traços sócio-culturais sob o risco de desaparecimento é insuficiente. Analisando de dentro pra fora é possível perceber a complexa teia de relações em que o tempo ecológico consegue marcar ou estruturar boa parte da organização social deste segmento, o que lhe confere certa especificidade.

Se por um lado, a vida urbana funcionava como "atrativo ideológico", como um convite a abandonar o local e o que ele proporciona - ritmo temporal diferenciado, por outro lado, funciona como exemplo do que eles não querem, ou seja, ao entrarem em contato com a realidade em que vivem seus ex-vizinhos e/ou parentes, se quebra a ilusão, a magia (ideologia) que permeia a vida moderna, urbana ou semi-urbana.

Alguns avaliam que é melhor deixar o local definitivamente, vender os terrenos para tentar se integrar na outra lógica, procurando se estabelecer com um emprego fixo, que é difícil por causa da formação/qualificação, ou no subemprego, os chamados "bicos". Outros avaliam que é melhor sair, mas permanecer com os terrenos, como uma estratégia que auxilia a sobrevivência no outro local, onde vão tentar a vida desenvolvendo a atividade de pequeno comerciante e vendedor de açaí beneficiado, o qual é extraído do terreno não vendido, considerado como uma garantia, caso a vida no novo local não dê certo. Outros são contratados pelo poder público, como é o caso do barqueiro da Escola Bosque e da Agente de Saúde, ou por empresas de pesca industrial e comercial, para atuarem como pescadores, em determinados períodos do ano. Outros preferem reforçar o ritmo temporal e a vida no local, com relativa autonomia em relação, principalmente, aos aspectos negativos da urbanização, da modernização, do mercado, do tempo mecânico ou linear.

Estes últimos, especialmente, comparam os estilos de vida e percebem as desvantagens da vida urbana ou semi-urbana. E a grande preocupação é com a sobrevivência/subsistência, como eles próprios relatam:

"Aqui é mais fácil pra pegá peixe, camarão, lá é só comprado" (COSME DA COSTA, 42 anos).

"Aqui não precisa pagá energia, só o óleo ou querosene pra lamparina, não precisa pagá água". (ALEXANDRE, 43 anos).

Latitude, vol. 5, n², pp.75-109, 2011. 


\section{As (Im)Possibilidades de Sustentabilidade do Modo de Vida Ribeirinho: Estudo sobre um Grupo Social na Área Insular do Município de Belém-Pa}

"A gente chegou, nasceu, se criou aqui, cada um no seu mato. Na cidade a gente vai ter que comprá açaí" (MANOEL MARIA, 56 anos).

"As crianças vão se soltá, aqui dentro a gente tem a possibilidade de segurá mais" (ESMELINDA, 39 anos).

"Na cidade é barulhento, tem ladrão, imagine se a gente pode vivê assim numa casa sem porta e janela, pode deixá aí que ninguém mexe. A segurança que a gente tem aqui é essa" (RONALDO DA COSTA, 45 anos).

Tomando como base a vivência/experiência dessas pessoas nos dois mundos/tempos e a comparação que estabelecem entre estes, é possível perceber diferença da situação argelina, na qual:

A ordem tradicional não é viável senão a condição de ser aproveitada, não como a melhor possível, mas como a única possível, a condição de que sejam ignorados todos os 'possíveis laterais' que encerram em si a pior ameaça unicamente pelo fato de que eles fariam aparecer a ordem tradicional, tida por imutável e necessária, como um possível entre outros, isto é, como arbitrário. Trata-se da sobrevivência do tradicionalismo que é ignorado como tal, isto é, como escolha que se ignora (BOURDIEU, 1979, p. 49).

Nesse sentido, faz-se necessário superar a idéia que concebe a sociedade tradicional como sem história, parada no tempo, ou regida por um tempo cíclico.

\section{TEMPOS E HISTÓRIA}

Este tipo de interpretação ahistórica, pode estar relacionado à orientação metodológica, ou seja, a capacidade de percepção do observador, como esclarece o antropólogo inglês LEACH (1974), argumentando que em nosso modo convencional de pensar, todo intervalo de tempo é marcado pela repetição. E, adverte que ao descrevemos tais seqüências como 'cíclicas', introduzimos inocentemente uma notação geométrica que pode muito bem estar ausente de uma maneira total do pensamento da população em questão.

Assim, pode-se recorrer à antropologia política, que:

[...] renova o velho debate relativo à relação das sociedades tradicionais (ou arcaicas) com a história. [...] Já não se pode fazer de conta que o tempo histórico das sociedades tradicionais se acha próximo do marco zero: um tempo da simples repetição (BALANDIER, 1969, p. 175). 
No caso do Jamaci, esse aspecto cíclico não está ausente, mas coexiste com outra forma que podemos considerar como continuidade, como ilustra o depoimento de uma moradora:

Antigamente as coisa era mais difícil pra gente, como diz o pessual, era muito cruel pra gente (...) começava desda farinha, a cumida as vezes tinha avoltado, mas a farinha num tinha e pra gente comprá um quilo de farinha a gente andava muito (DONA ESTER, 84 anos).

Ao comparar o tempo de antigamente com o tempo atual, a moradora explicita certa noção de historicidade. Mas, isso não significa, em hipótese alguma, que esta inserção seja entendida numa perspectiva linear ou evolucionista. Tratase, ao contrário, de outra proposição:

Talvez para resolver essa questão, seria interessante propor-se um caminho que privilegiasse as realidades sociais e culturais e suas respectivas complexidades, isto é, trabalhar com a noção de casos-limites ou situações polares da fronteira tradicionalismo/modernidade, que parece permear em diferentes níveis distintos grupos humanos (FORLINE e FURTADO, 2002, p. 212).

A idéia aqui é enfatizar a coexistência temporal, numa perspectiva dinâmica, como explicitam os autores referidos, ao refletirem sobre as populações tradicionais na Amazônia:

Na realidade, em diferentes planos da vida material e social dos povos, o tradicionalismo e a modernidade se mesclam ou assumem status diferentes num mesmo grupo social. Há, evidentemente, casos em que um status predomina ou mesmo supera o outro. Cabe ao investigador uma etnografia fina da sociedade com a qual ele trabalha, para avaliar o status de tradicionalismo e de modernidade [...] O importante é reconhecer o status do grupo social ou das populações ditas "tradicionais" no interior desse espaço (Amazônia), onde se identificam as duas situações polares-pares; é reconhecer o ser do grupo (indígena, caboclo, migrante, quilombola, urbano); é atribuir-lhe o valor intrínseco de seus processos sociais, as lógicas internas, a razão prática de sua existência material e social; é recortar como um bricoleur, os contornos socioculturais das unidades sociais com as 


\title{
As (Im)Possibilidades de Sustentabilidade do Modo de Vida Ribeirinho: Estudo sobre um Grupo Social na Área Insular do Município de Belém-Pa
}

\author{
quais entramos em contato (FORLINE e FURTADO, \\ 2002, p. 212-213).
}

A noção polares-pares não deve ser entendida num sentido simplista $\mathrm{e}$ dicotômico, mas sim num sentido complexo, no qual possamos pensar numa realidade em movimento.

A relação entre as noções de fartura e escassez, recorrente em outros trabalhos como: LEITÃO (1997); NASCIMENTO (1993); e VILHENA (2005), pode ser considerada como um indicativo de percepção, por parte desses pescadores, da irreversibilidade do tempo:

A questão do tempo está na encruzilhada do problema da existência e do conhecimento [...] a irreversibilidade não pode mais ser identificada com uma mera aparência que desapareceria se tivéssemos acesso a um conhecimento perfeito (PRIGOGINE, 1996, p.9-11).

Assim, pode-se pensar, tomando por base Morin (2003), na existência de um tempo que se divide em dois: o tempo seqüencial (irreversível) e o tempo circular. Segundo o autor, estes dois tempos se envolvem, se entrelaçam, se interrompem, se fundem, se opõem e se complementam: o primeiro é irreversível e desintegrador, o segundo é repetitivo, age em prol da regeneração, da reintegração, portanto, são distintos e antagônicos. Desse modo, pode-se relacionar a noção de tempo ao formato de uma espiral, superando assim a perspectiva simplista e excludente que só consegue conceber a existência de um ou de outro tempo e de forma linear e seqüencial. Esse duplo tempo comporta a diversidade e une os diferentes tempos complementares, concorrentes e antagônicos que constituem juntos o tempo da vida:

O tempo da vida é, com efeito, o tempo dos nascimentos, o tempo dos desenvolvimentos, o tempo dos declínios e das mortes e o tempo dos ciclos (desde o ciclo ecológico do dia e da noite, que comanda os ciclos do carbono e do oxigênio, até o ciclo das estações, que comanda os ciclos das reproduções, passando pelo ciclo ininterrupto do metabolismo e do circuito homeostático do organismo) (MORIN, 2003, p. 267).

Tanto os moradores que permaneceram, como alguns dos que saíram, parecem conscientes das mazelas sociais da vida "moderna", como, o desemprego, violência e insegurança social de modo mais geral. Por isso, procuram reforçar os valores locais como garantia de se reproduzirem. Mas isso não significa que sejam totalmente contrários ou indiferentes ao que a vida moderna, urbana, pode 
proporcionar. Desde que não afete a segurança que o atual estilo de vida thes proporciona.

A experiência jamaciense, de forma análoga à realidade dos ribeirinhos amazonenses:

[...] convida-nos a refletir sobre uma combinação entre o melhor da modernidade: a) educação adequada, b) acesso à assistência médica, c) empowermet como cidadão; e o melhor das sociedades tradicionais: a) atenção às necessidades básicas de todos os membros (inclusive a dos menos sucedidos: doentes, desempregados...; e as crianças e os velhos), b) satisfação humana derivada de valores além dos materiais e, especialmente, (c) uma atitude conservacionista para com a natureza (LEWISMAYBURY, 1997, p. 56).

Em nenhum momento pretendi negar a presença da lógica econômica e da consciência temporal dominantes, assim como não busquei passar a idéia de outra tradição cultural pura ou isolada. O que tentei mostrar é que, fundamentalmente, trata-se de uma (re)invenção criadora, muito diferente de certa perspectiva evolucionista segundo a qual esse segmento social recebe as imposições de forma mecânica e passiva.

A possibilidade da permanência do estilo de vida ribeirinho não deve ser descartada, tendo em vista que atualmente as atenções dos gestores das políticas ambientais internacionais se voltam para práticas concretas apresentadas como experiências de desenvolvimento sustentável. Trata-se de várias práticas sociais de diversos grupos amazônicos que, por muito tempo, foram vistos como atrasados, antimodernos, primitivos, contrários ao desenvolvimento, à ciência e à civilização. Hoje são reconhecidos, e tornam-se modelos de sustentabilidade e de equilíbrio no contexto ambiental.

Isso pode significar, por um lado, o reconhecimento da existência de vários tempos:

$\mathrm{O}$ que constitui a própria originalidade no século $\mathrm{XX}$, a constituição de um espaço-tempo planetário complexo em que as sociedades tomadas num mesmo tempo vivem tempos distintos: tempo arcaico, tempo rural, tempo industrial, tempo pós-industrial etc. Tudo isso deve levar-nos a romper com a idéia segundo a qual, daqui para a frente, devemos alinhar todas as sociedades no tempo mais rápido, o tempo cronometrado, o tempo ocidental. Isto deve levar-nos, antes, a viver a complementaridade dos distintos tempos, a conter a 


\section{As (Im)Possibilidades de Sustentabilidade do Modo de Vida Ribeirinho: Estudo sobre um Grupo Social na Área Insular do Município de Belém-Pa}

invasão do tempo cronometrado, a desacelerar o tempo ocidental (MORIN e KERN, 2003, p.148).

Por outro lado, levanta dúvidas sobre os reais interesses envolvidos nesse processo: será que a crise ambiental planetária pode ser resolvida com a preservação da biodiversidade de algumas áreas da Amazônia ou dos países do Terceiro Mundo? Ou será que está se desviando o foco de atenção dos problemas de poluição e do consumismo dos países desenvolvidos?

Segundo FERNANDES (2003), as atuais políticas internacionais não respondem aos problemas ecológicos reais, mas procuram manter a hegemonia da lógica de organização capitalista, a partir do controle dos recursos naturais renováveis e não renováveis do planeta, pois essas políticas são muito mais determinadas pelas relações de poder do que pelos problemas de limites e escassez de recursos naturais que as sociedades podem enfrentar.

A Amazônia é uma região muito complexa, por uma série de fatores como: grande extensão territorial; vários ecossistemas; diversidade étnica e cultural; vários atores; várias concepções e interesses diferentes e até contraditórios. Portanto, jamais deve ser estudada a partir de uma perspectiva simplificadora. É necessário, como sugerem LIMA e POZZOBON (2001), superar as clássicas dicotomias sociológicas entre branco $\mathrm{x}$ índio, camponês $\mathrm{x}$ latifundiário, mercado $\mathrm{x}$ consumo e outras, para explicar a heterogeneidade na relação com o meio ambiente. Sempre considerando a questão histórica, isto é, sem perder de vista que o comportamento de um determinado segmento social, em relação ao ambiente, é definido pela conjugação particular de suas características sociais em um dado momento e lugar.

Desse modo, não se deve pensar uma única atividade para toda a Amazônia, nem tampouco conceber a relação entre as várias atividades como concorrentes, mas sim, como complementares:

A evolução da pesquisa sócio-ambiental no Brasil está exigindo, finalmente um tipo especial de análise integrada de sistemas regionais que possam subsidiar a criação de estratégias consistentes de ecodesenvolvimento [...] A gestão da complexidade constitui, entretanto, o principal obstáculo a ser enfrentado pelos analistas e planejadores de novas estratégias socialmente justas, economicamente viáveis, ecologicamente prudentes e politicamente emancipadoras de desenvolvimento regional (VIEIRA, 1992: 17). 
João Luiz da Silva Lopes

Trabalhar na perspectiva das especificidades e potencialidades locais é, talvez, uma possibilidade de alcançarmos a sustentabilidade, sem ignorar as relações entre as várias escalas: local, regional, nacional e global.

A desconstrução da racionalidade capitalista é uma utopia, com o propósito de construir uma racionalidade social alternativa que supere as desigualdades sociais, reconheça a diversidade cultural e respeite os tempos e ritmos ecológicos e sociais.

\section{Considerações finais.}

A experiência jamaciense, em suas especialidades problematiza as análises evolucionistas (futuro comum); as análises funcionalistas (relações sociais iguais a sistemas orgânicos) e as estruturalistas (estruturas fixas, sem história), pois as mudanças ocorridas nas formas de organização social, na relação com o meio ambiente físico, na incorporação de outras técnicas, no destino da produção, na atualização do universo simbólico, na relação com o mercado, na interação com o tempo "moderno" são dinâmicas de interação e mutação inerentes a toda organização social, abordada numa perspectiva histórica.

Um indicativo da especificidade da lógica de vida dos jamacienses é o fato de não controlarem a produção e os rendimentos - prática bastante distinta daquela vivenciada nos empreendimentos tipicamente capitalistas. Portanto, não se pode afirmar que a interação com o mercado signifique, necessariamente, uma intencionalidade de acumulação de riquezas. Tampouco, significa que esse segmento social, a partir do contato com o mercado, passe a ser regido totalmente pela lógica da troca mercantil, pois se trata, primordialmente, de uma estratégia de reprodução, tendo em vista que há muito tempo realizam trocas e o mercado é apenas mais um dos elementos dessa interação, com a diferença de ser intermediado pela moeda.

A especificidade do estilo de vida ribeirinho e de sua produção se deve a um conjunto de diversos fatores, tais como: não distinção rígida entre a produção para o auto-consumo e para a comercialização; diversidade de práticas produtivas (não especialização ou monoculturas); variação/oscilação na produção devido à influência dos ritmos ecológicos; mobilidade dos recursos, no caso do peixe e camarão; utilização de técnicas "artesanais"; e, sobretudo, valores culturais e suas simbologias.

Os valores culturais, as simbologias, as condições naturais que variam de acordo com os ritmos ecológicos, os equipamentos técnicos, assim como as relações de parentesco e as diferenças de sexo e idade, influenciam na organização social e orientam, regulando de certa forma, a realização das práticas produtivas.

Latitude, vol. 5, n², pp.75-109, 2011. 


\section{As (Im)Possibilidades de Sustentabilidade do Modo de Vida Ribeirinho: Estudo sobre um Grupo Social na Área Insular do Município de Belém-Pa}

Nesse sentido, é premente superar a simplificação, a dicotomização e toda forma de determinismo, para que possamos perceber as relações sociais em toda a sua fundamental complexidade, o que significa levar em conta que as conexões entre as lógicas temporais e econômicas são - simultaneamente - complementares, concorrentes, antagonistas e incertas.

Mas essa superação, não pode ser pensada de maneira dissociada da correlação de forças, na forma de conceber a relação entre sociedade e natureza, a qual interfere diretamente na formulação e concretização das políticas ambientais, sociais, econômicas e culturais em escala local, regional, nacional e global.

\section{Referências}

BALANDIER, Georges. Antropologia Política. São Paulo: Editora da Universidade de São Paulo, 1969.

BAREL, Yves. La Reproducion Sociale. Paris: Anthropos, 1973.

BOURDIEU, Pierre. O Desencantamento do Mundo: Estruturas Econômicas e Estruturas Temporais. São Paulo: Perspectiva, 1979.

BOURDIEU, Pierre. As Estruturas Sociais da Economia. Porto: Campo das Letras, 2006.

CASTRO, Edna. Tradição e Modernidade. A propósito de processos de trabalho na Amazônia.

Novos Cadernos NAEA, Belém, vol. 2, no 1, p. 31-50, dezembro 1999.

CASTRO, Edna. Território, Biodiversidade e Saberes de Populações Tradicionais. In: DIEGUES, Antonio Carlos. Etnoconservação: novos rumos para a proteção da natureza nos trópicos. São Paulo: HUCITEC/NUPAUB, USP, 2000.

CLASTRES, Pierre. A Sociedade Contra o Estado. 5 ed. São Paulo: Francisco Alves, 1990.

COLLART, Olga Odinetz. Ecologia e Potencial Pesqueiro do Camarão-Canela, (Macrobrachim Amazonicum), na Bacia Amazônica. Bases Científicas para Estratégia de Preservação e Desenvolvimento da Amazônia, Instituto Nacional de Pesquisas da Amazônia, Manaus, vol. 2, p. 147-166, 1993.

CONCEIÇÃO, Maria de Fátima Carneiro. Populações Tradicionais, Sociabilidade e Reordenação Social na Amazônia. In: JACKSON, Maria José (org.). Sociologia na Amazônia: debates teóricos e experiências de pesquisa. Belém: Universidade Federal do Pará, 2001.

CUNHA, Lucia Helena. Tempo Natural e Tempo Mercantil na Pesca Artesanal. In: DIEGUES, Antonio Carlos. Imagem das Águas. São Paulo: HUCITEC/NUPAUB, USP, 2000. 
João Luiz da Silva Lopes

DIEGUES, Antonio Carlos. Etnoconservação da natureza: enfoques alternativos. In: . Etnoconservação: novos rumos para a proteção da natureza nos trópicos. São Paulo: HUCITEC/NUPAUB, USP, 2000.

DURHAM, Eunice. Os Problemas atuais da pesquisa antropológica no Brasil. Revista de Antropologia, São Paulo, vol. 25, Departamento de C. Sociais (Antropologia) - Faculdade de Filosofia, Letras e C. Humanas - Universidade de São Paulo, p. 158-183, 1982.

ELIAS, Norbert. O Processo Civilizador: Formação do Estado e Civilização, vol. 1. Rio de Janeiro: Jorge Zahar,1993.

EVANS-PRITCHARD, E. Os Nuer. São Paulo: Editora Perspectiva/Estudo, 1978.

FERNANDES, Marcionila. Desenvolvimento Sustentável: antinomias de um conceito. In: FERNANDES, M. e GUERRA, L. (Org.) Contra-Discurso do Desenvolvimento Sustentável. Belém: Associação de Universidades Amazônicas, 2003.

FORLINE, Louis \& FURTADO, Lourdes. Novas reflexões para o estudo das Populações Tradicionais na Amazônia: por uma revisão de conceitos e agendas estratégicas. Boletim do Museu Paraense Emilio Goeldi, Belém, Série Antropologia, vol. 18, no 2, p. 195-217, 2002.

FRANCO, Maria Sylvia. Homens Livres na Ordem Escravocrata. 3 ed. São Paulo: Kairós, 1983.

HIRAOKA, Mário. Mudanças nos padrões econômicos de uma população ribeirinha do estuário amazônico. In. FURTADO, L.; LEITÃO, W.; MELO, A. (org.). Povos das Águas: realidades e perspectivas na Amazônia. Belém: Museu Paraense Emilio Goeldi, 1993.

GODELIER, Maurice. A Parte ideal do real. In. CARVALHO, Edgar. (org). GodelierAntropologia. São Paulo: Ática, 1981.

GROSSMANN, Mônica. et all. Planejamento participativo visando a um manejo sustentável dos açaizais no estuário amazônico e regulamentações oficiais. In: JARDIM, M; MOURÃO, L. \& GROSSMANN, M. Açaí: possibilidades e limites para o desenvolvimento sustentável no estuário amazônico. Belém: Museu Paraense Emilio Goeldi, 2004.

LEACH, Edmund. Repensando a Antropologia. São Paulo: Perspectiva, 1974.

LEITÃO, Wilma. O Pescador Mesmo: um estudo sobre o pescador e as políticas de desenvolvimento da pesca no Brasil. Dissertação (Mestrado em Antropologia) Universidade Federal do Pará. Belém, 1997.

LIMA, Déborah. A Construção Histórica do termo Caboclo: sobre estruturas e representações sociais no meio rural amazônico. Novos Cadernos NAEA, Belém, vol. 2, no 2, p. 5-32, dezembro de 1999.

LIMA, Déborah \& POZZOBON, Jorge. Amazônia Socioambiental: sustentabilidade ecológica e diversidade social. In. VIEIRA, I.; SILVA, J. M.;OREN, D. \& D'INCAO,

Latitude, vol. 5, n², pp.75-109, 2011. 


\section{As (Im)Possibilidades de Sustentabilidade do Modo de Vida Ribeirinho: Estudo sobre um Grupo Social na Área Insular do Município de Belém-Pa}

M. A. (orgs) Diversidade biológica e cultural da Amazônia. Belém, Museu Paraense Emílio Goeldi, 2001.

MAYBURY-LEWIS, Biorn. Terra e água: identidade camponesa como referência de organização política entre os ribeirinhos do rio Solimões. In. FURTADO, Lourdes. (org) Amazônia: desenvolvimento, sociodiversidade e qualidade de vida. Belém: UFPA/NUMA, 1997.

MAUÉS, Raymundo Heraldo. Uma Outra "Invenção" da Amazônia: Religiões, Histórias, Identidades. Belém: Cejup, 1999.

MOREIRA, Edma do Socorro. Tradição em Tempos de Modernidade: reprodução social numa comunidade varzeira do Rio Xingu/PA. 2002. 122f. Dissertação (Mestrado em Sociologia) - Universidade Federal do Pará. Departamento de Sociologia, Belém, 2002.

MOREIRA NETO, Carlos. Índios da Amazônia: de Maioria a Minoria (1750-1850). Petrópolis: Vozes, 1988.

MORIN, Edgar \& KERN, Anne. Terra-Pátria. Porto Alegre, Sulina, 2003.

MORIN, Edgar. Método 1 A Natureza da Natureza. Porto Alegre: Sulina, 2a Edição, 2003.

NASCIMENTO, Ivete. Homens e peixes: o tempo da pesca artesanal. Dissertação (Mestrado em Antropologia) - Universidade Federal da Paraíba, João pessoa, 1995. PREFEITURA MUNICIPAL DE BELÉM. Anuário Estatístico do Município de Belém - 1999. Belém: PMB, 1999.

PRIGOGINE, Ilya. O Fim das Certezas: Tempo, Caos e as Leis da Natureza. São Paulo: Unesp, 1996.

SIMONIAN, Lígia (org.). Gestão em ilha de muitos recursos, história e habitantes: experiências na Trambioca-Barcarena PA. Belém: NAEA/UFPA, 2004.

THOMPSOM E. P. Tiempo, disciplina de trabajo y capitalismo industrial. Barcelona: Editora Crítica, 1984.

VILHENA, Josiel. Relação Sociedade/Natureza: adapitabilidade humana frente à escassez de pescado em uma área do estuário amazônico. Dissertação (Mestrado em Sociologia) - Universidade Federal do Pará. Belém, 2005.

ZELIZZER, Viviana. O Significado Social do Dinheiro: dinheiros especiais. In: PEIXOTO, J. e MARQUES, R. (orgs.) A Nova Sociologia Econômica. Oeiras: Celta, 2003. 
João Luiz da Silva Lopes

Latitude, vol. 5, n², pp.75-109, 2011. 